Article

\title{
Concentration and Size Distribution of Culturable Bacteria in Ambient Air during Spring and Winter in Gliwice: A Typical Urban Area
}

\author{
Ewa Brągoszewska, Anna Mainka * and Jozef S. Pastuszka \\ Department of Air Protection, Silesian University of Technology, 22B Konarskiego St., 44-100 Gliwice, Poland; \\ Ewa.Bragoszewska@polsl.pl (E.B.); Jozef.Pastuszka@polsl.p (J.S.P.) \\ * Correspondence: Anna.Mainka@polsl.pl; Tel.: +48-322-371-060
}

Received: 11 October 2017; Accepted: 29 November 2017; Published: 1 December 2017

\begin{abstract}
The concentrations and size distributions of culturable bacterial aerosols were measured during spring and winter in outdoor air in Gliwice, Upper Silesia, Poland. This research on culturable bacteria was carried over a period of two years. The samples were collected using a six-stage Andersen cascade impactor (with aerodynamic cut-off diameters of 7.0, 4.7, 3.3, 2.1, 1.1, and $0.65 \mu \mathrm{m}$ ). The results showed that the average concentration of culturable bacterial aerosol was $355 \mathrm{CFU} \mathrm{m} \mathrm{m}^{-3}$ in spring,

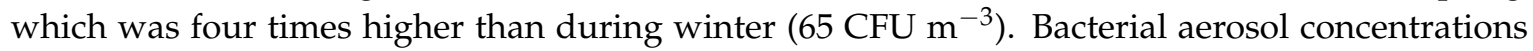
showed the unimodal size distribution with the highest range of 3.3-4.7 $\mu \mathrm{m}$ particles. The seasonal distributions of bacterial aerosol grain clearly indicate that, in winter, the size distribution of particles $<7 \mu \mathrm{m}$ is more "flattened" and is characterized by an increased share of fine fractions and a decreased share of coarse ones. Environmental parameters, such as temperature, UV radiation, relative humidity, wind velocity, as well as $\mathrm{PM}_{10}$ and $\mathrm{PM}_{2.5}$ concentrations, were measured in order to analyse whether environmental factors had any effect on bacterial aerosols. Statistically, the most important meteorological factors in the viability of airborne bacteria were temperature and UV radiation.
\end{abstract}

Keywords: outdoor air; bacterial aerosols; size distribution; meteorological parameters; correlation

\section{Introduction}

Airborne microbes are an abundant component of atmospheric aerosols, with thousands, or even millions, of cells in each cubic metre of air [1,2]. The comprehensive monitoring of atmospheric bioaerosol concentrations is very important, not only for environmental management, but also to assess the health impact of air pollution. This is because bioaerosols can cause a variety of infectious diseases, as well as allergic and toxic reactions [3-6]. Bacterial aerosols are dispersed into the air from various sources, such as soil, plants, and water, as well as through the activities of animals, humans, and industrial operations, all of which can occur in the urban environment [7]. In ambient air, bacterial aerosols are often less abundant than fungal spores or pollen grains and rarely cause serious human illness [8]. Particularly well documented are negative effects that bioaerosols can play on the human respiratory system spanning from infectious diseases to allergies, and asthma $[9,10]$. However, they can contain cell membrane antigens such as endotoxin and peptidoglycans, which may damage lung tissue and induce serious respiratory symptoms $[7,11]$. It is important to note, that infectious and non-infectious diseases depend not only on the biological properties of bioaerosols, but also on the site of their deposition in the respiratory tract. The deposition of particles in the respiratory tract is directly related to the aerodynamic diameter of the particles and their effect on human health depends highly on their physical properties, and particularly on their size distribution [12]. 
Bacteria and microscopic fungi cells are 0.3 to $100 \mu \mathrm{m}$ in diameter (aerodynamic diameter). The size distribution of bioaerosols depends on the type of microorganism species, the age of the spore and nutrient medium, humidity, differences in aggregation rates of the spores, and the type of particles with which the spores are associated, such as mist or dust. It should be noted that bioaerosol particles can occur in the air as single cells or aggregates of cells, as well as in fragments. They are often transported attached to other particles, such as skin flakes, soil, dust, saliva, or water droplets $[3,13]$.

Numerous studies have demonstrated the adverse health effects of exposure to biological agents, but most of them have focused on occupational and indoor environments because humans spend the majority of their time in these environments [14-21]. There is still very little information about the level of bacterial aerosol concentrations in ambient air. Meanwhile, information about the concentration of bacteria in the ground layer of the atmosphere is crucial in predicting the effects of breathing outdoor air on human health.

To date, bioaerosols have been measured in many indoor environments [18,20-22], including residential and public buildings $[12,15]$, schools and nurseries $[14,16,17,23]$. Some studies have indicated that the concentration and size distribution of bioaerosols vary greatly by region and by season, depending on biotic and abiotic factors, such as the species of microorganism, environmental conditions, or human activities [24-30]. The role of geography and climate on concentrations of outdoor bacteria is important because the transport of bioaerosols is primarily governed by hydrodynamic and kinetic factors, while their fate is dependent on their specific chemical composition and the meteorological factors to which they are exposed [24,31-33]. The meteorological factors with major roles to play in bioaerosol concentrations and their transport are air temperature $(\mathrm{T})$, relative humidity $(\mathrm{RH})$, wind velocity (WV) and UV radiation (UV) $[24,27,28]$. Moreover, particulate matter (PM) in the atmosphere may influence bioaerosol concentrations. Gao et al. [34] showed that $\mathrm{PM}_{10}$ and $\mathrm{PM}_{2.5}$ have a statistically significant relationship with some bioaerosol characteristics. $\mathrm{PM}_{2.5}$ appeared to have a unanimously negative correlation with culturable bioaerosol concentrations. A possible reason for this is that $\mathrm{PM}_{2.5}$ usually contains soot, metals, and secondary inorganic components, which have a negative effect on the cultivation and survival of bioaerosols. However, the effect of $\mathrm{PM}_{10}$ on bioaerosols was different. Probably because the concentration of bioaerosols attached to coarse solid particles increases as PM accumulates. Meanwhile, limited chemicals in coarse particles, including mineral species from soil and particles of biological origin, had no obvious poisonous effect [34].

Although there have been studies presenting the relationship between different weather conditions and bioaerosol concentrations, the size distribution of bacterial aerosols and its relationship with different meteorological factors has been only preliminary recognized. Moreover, our previous studies conducted in Upper Silesia, Poland, showed that the highest concentrations of airborne bacteria in outdoor air occur in spring, while the lowest occur in winter $[17,23,35]$. Therefore, it is essential to explain the influence of meteorological parameters on the concentration and size distribution of bacterial bioaerosols in moderate climate zones.

The present study was carried out in a typical Eastern European urban city, with the aim of filling these knowledge gaps. Therefore, in this study, we investigated the concentration levels of culturable bacterial aerosols, their size distribution, as well as seasonal (spring-winter) variations in the outdoor air in Gliwice, a town in Southern Poland. In this work, we focused on culturable bacteria only, because these microorganisms are very sensitive to interaction with other air pollutants, e.g., $\mathrm{PM}_{2.5}$ and $\mathrm{PM}_{10}$, and seem to be highly influenced by a variety of meteorological factors. Thus, to better understand these atmospheric dynamics under different conditions, a particular investigation of the complicated interrelationships between environmental factors and bioaerosols is needed. Moreover, this study can increase awareness of the influence of bioaerosols on human health, as well as provide references for a better understanding of OAQ (outdoor air quality) in the urban areas of developing countries. The data presented herein also indicate the need to control environmental pollution (through the future determination of an official European OAQ standard), thereby preventing human respiratory disease as a result of outdoor atmospheric exposure. 


\subsection{Sampling Sites}

The study was carried out in Gliwice $\left(50^{\circ} 17^{\prime} 37.1^{\prime \prime} \mathrm{N} 18^{\circ} 40^{\prime} 54.9^{\prime \prime} \mathrm{E}\right)$, a typical city in the industrial region of Upper Silesia, Poland (a region containing 4.5 million people). The measurement point was located in the city centre, about $500 \mathrm{~m}$ from a busy road (Figure 1). The nearest surroundings to the sampling point were characterized by compact building development, i.e., buildings, roads, pavements, etc., covering most of the surface of this part of the city. The field sampling of ambient bioaerosols was carried out at human head height (approx. $1.5 \mathrm{~m}$ ) above ground level.

Air sampling was conducted during two seasons (spring and winter) in 2015 and 2016. The spring season was conventionally assumed to last from mid-March to mid-June, while the winter months were assumed to last from mid-December to mid-March. A total of 150 measurements were taken for this study. Every measurement was conducted between 10:00 a.m. and 11:00 a.m. during the campaign period. The most important meteorological parameters, such as air temperature (T), relative humidity $(\mathrm{RH})$ and wind velocity (WV), were recorded at the sampling sites using an Oregon Scientific WMR200 weather station (Oregon Scientific, Portland, OR, USA). On the other hand, $\mathrm{PM}_{10}, \mathrm{PM}_{2.5}$, and UV radiation (UV) measurements were obtained from automatic measurement stations made accessible by the Provincial Inspectorate for Environmental Protection (WIOŚ). They were collected during the sampling periods at the urban background station in Zabrze and the regional background station in Gliwice, located beyond the range of influence of Gliwice city.

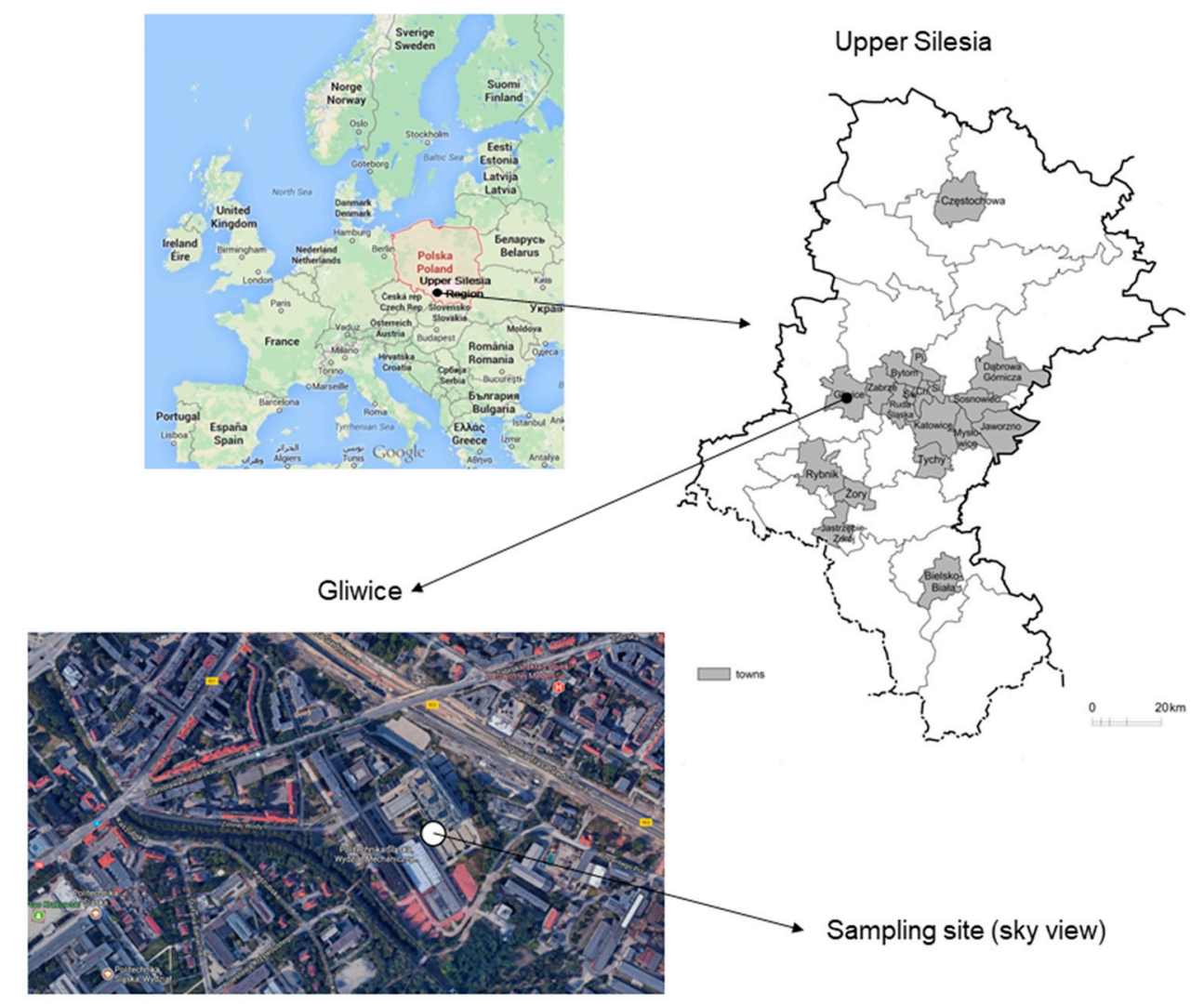

Figure 1. Location of bioaerosol measurement campaign (map data: 2017@ Google, ORION-ME).

\subsection{Sampling and Analysis Methods}

The air samples were collected using a six-stage Andersen cascade impactor (Tisch Environmental Inc., Cleves, $\mathrm{OH}, \mathrm{USA})$. The aerodynamic diameter ranges for each stage are as follows: stage 1 $(>7 \mu \mathrm{m})$, stage $2(4.7-7 \mu \mathrm{m})$, stage $3(3.3-4.7 \mu \mathrm{m})$, stage $4(2.1-3.3 \mu \mathrm{m})$, stage $5(1.1-2.1 \mu \mathrm{m})$, and stage $6(0.65-1.1 \mu \mathrm{m})$. The impactor also comprises a pump, which provides a constant flow 
rate (28.3 $\left.\mathrm{L} \mathrm{min}^{-1}\right)$ during measurement. The sampling time, following Nevalainen et al. [3,36], was $10 \mathrm{~min}$. The microorganisms were collected on nutrient media in Petri dishes located on all impactor stages. The impactors were disinfected with $70 \%$ ethanol-immersed cotton balls between each sampling. Tryptic soy agar (TSA) was used for the bacteria, with cycloheximide added to inhibit fungal growth. The bacteria were counted according to the Polish Standard [23]. It is important to note that, although it is extremely difficult to directly measure the concentrations of living airborne bacteria, the commonly-used substitute for the concentrations of living microorganisms present in the air is the number of colony forming units in the volume of air $\left(\mathrm{CFU} \mathrm{m} \mathrm{m}^{-3}\right)$. It should be noted that the culture-based method employed in this study includes probably only about $10 \%$ of the total microorganisms [29]; however, it still provides valuable information for the assessment of human exposure and the establishment of a Polish official standard governing the levels of bioaerosols in ambient air.

The quality control was performed by using PN-EN12322 [37] and ISO 11133 [38] standards, with the same operation details as in our previous studies $[17,23]$.

\subsection{Statistical Analysis}

All statistical analyses were performed using the Statistica 12 statistical package (StatSoft). The concentration values reported below were presented as the mean values and standard deviation. Given the fact that the data were not normally distributed, a nonparametric method was employed. The Mann-Whitney test was applied to assess seasonal differences at the sampling site. Spearman's rank correlation coefficient was used to evaluate the statistical dependence between airborne bacterial concentrations and meteorological parameters, including temperature $(\mathrm{T})$, relative humidity (RH), wind velocity (WV), UV radiation (UV), and $\mathrm{PM}_{10}$ and $\mathrm{PM}_{2.5}$ concentrations, separately for spring and winter. Significant differences were determined when a probability lower than $0.05(p<0.05)$ was considered.

\section{Results and Discussion}

\subsection{Bacterial Aerosol Concentrations during the Spring and Winter Seasons}

Figure 2A,B shows the concentrations of aerosol particles in the air in spring and winter. The concentrations of bacterial aerosols in the outdoor air ranged from 80 to $1124 \mathrm{CFU} \mathrm{m}{ }^{-3}$ in spring and from four to $265 \mathrm{CFU} \mathrm{m} \mathrm{m}^{-3}$ in winter. The average concentration of bacterial aerosol was found in spring $\left(355 \mathrm{CFU} \mathrm{m}^{-3}\right)$, and was more than five times higher than the average level recorded in winter $\left(65 \mathrm{CFU} \mathrm{m} \mathrm{m}^{-3}\right)$.

The values recorded in the outdoor air in Gliwice in winter are higher than to those obtained in studies conducted in Warsaw, Poland, where the average concentration of airborne bacteria in winter was $39 \mathrm{CFU} \mathrm{m}{ }^{-3}$ (range 35-126 CFU m ${ }^{-3}$ ) [22], and in Seoul, South Korea, where the average concentration of airborne bacteria in winter was $11 \mathrm{CFU} \mathrm{m}^{-3}$ (range 0-118 CFU m ${ }^{-3}$ ) [6]. In Ankara, Turkey, Mentese et al. [18], reported an average concentration of bacterial aerosol of $57 \mathrm{CFU} \mathrm{m}{ }^{-3}$ from December to March 2007. The lowest bacterial concentrations are observed in winter because extreme conditions, such as a decreased temperature and the heaviest rainfall and snowfall of the year, might contribute to decreased bacterial levels [28,39]. The values obtained in Gliwice are also comparable to data obtained in Colorado, USA and Montreal, Canada, where the lowest average bacterial aerosol concentrations were found in the winter and the highest were found in spring [1,40]. On the other hand, the definition of the season cannot be used as the only criteria for seasonal patterns. For example, Genitsaris et al. [41] underlined the higher concentration of bacterial aerosol in winter comparing to spring, while our results present the opposite trend. However, winter in Greece is characterized by the similar positive temperature levels, which promotes the growth of bacteria, as in Poland during spring. 

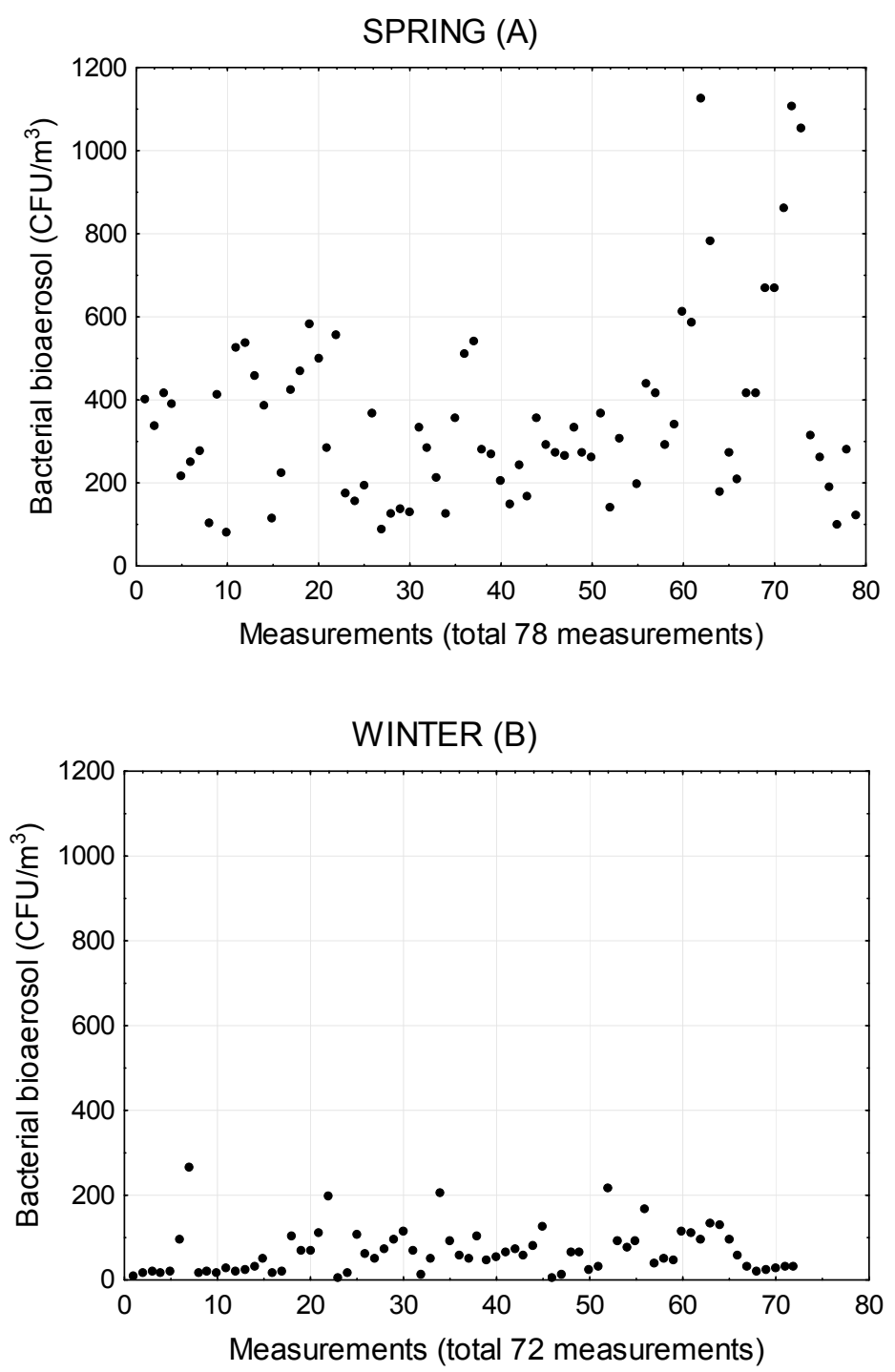

Figure 2. Concentration of culturable bacterial aerosols in outdoor air in spring (A) and winter (B).

Although in Poland, and many other countries, the legislation governing microbiological air pollution standards has not been developed and implemented according to the available literature, it can be seen that the concentration levels of bioaerosols obtained in our study are below the proposed standards. Górny [42], in a review of propositions for outdoor air, proposed a total bacterial concentration of $5000 \mathrm{CFU} \mathrm{\textrm {m } ^ { - 3 }}$ as the upper limit for regulatory bacterial aerosol levels. However, research by the Robert Sauvé Occupational Health and Safety Research Institute (IRSST) indicates that if the total concentration of airborne bacteria concentrations is $1000 \mathrm{CFU} \mathrm{m} \mathrm{m}^{-3}$, then microbial contamination is possible; this justifies further investigation of the situation and the requirement to take action [43].

\subsection{The Size Distribution of Bacterial Aerosols}

The aerodynamic diameters of bioaerosols determine their potential to be deposited either in the tracheal, bronchial, or alveolar regions of the lungs; thus, the effects of bioaerosols on human health are not only related to their concentrations, but also to their size distribution. The size distribution of airborne bacteria in spring and winter is shown in Figures 3 and 4. It can be seen that the airborne culturable bacteria collected in spring were distributed unimodally, however, in winter, 
the size distribution of bacterial particles was more "flattened" and was characterized by the increased contribution of fine bioparticles and a decreased contribution of coarse ones.

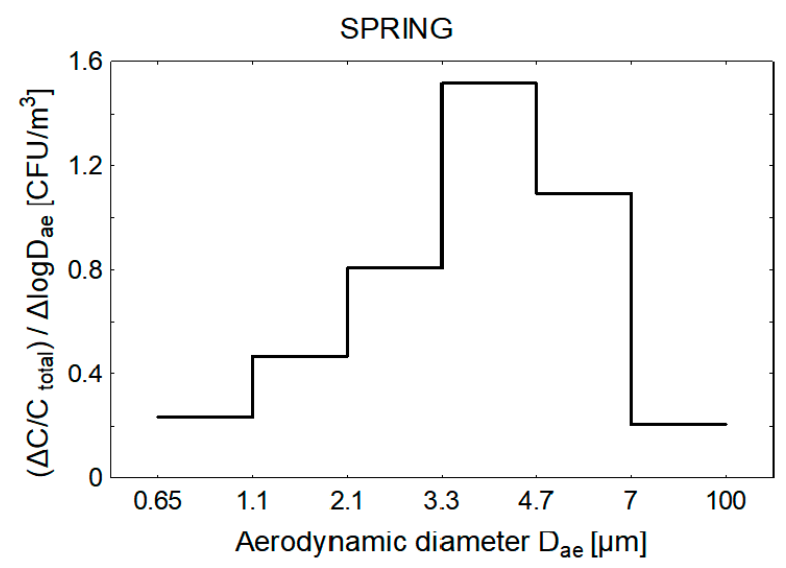

Figure 3. Size distribution of bacterial aerosols in outdoor air in spring.

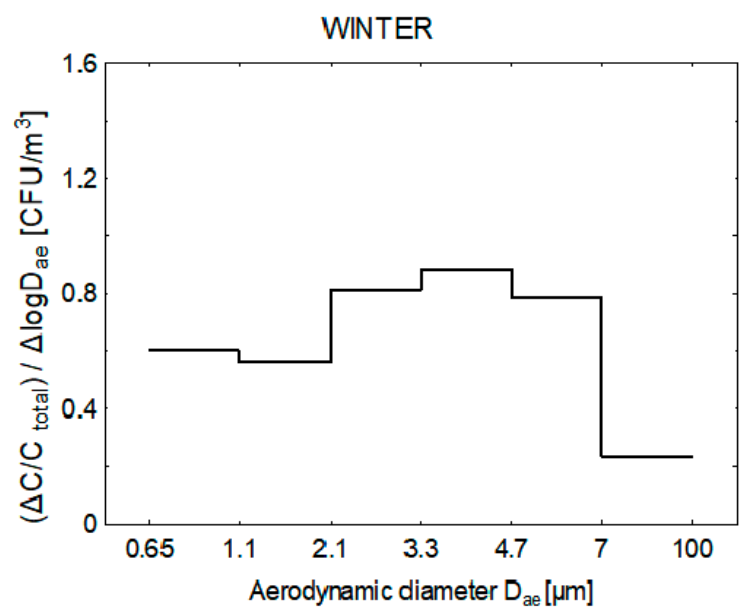

Figure 4. Size distribution of $\mathrm{t}$ bacterial aerosols in outdoor air in winter.

During both seasons, bacteria were primarily found as the coarse particles larger than $2.1 \mu \mathrm{m}$, with contributions of $81.8 \%$ and $78.2 \%$ during spring and winter, respectively. This seasonal difference was not statistically significant $(p>0.05)$.

It is also interesting that $53.9 \%$ and $59.2 \%$ of airborne bacteria were found within the size range of less than $4.7 \mu \mathrm{m}$ in spring and winter, respectively. This indicates that more than $50 \%$ of bacterial aerosols were in the respirable size range, regardless of the season. Respirable particles have the potential to be deposited either in the upper or lower respiratory tract. Therefore, exposure to ambient bacteria has potential adverse effects on human health during both spring and winter. Furthermore, the present results suggest that the respirable fraction of the bacteria in ambient air is comparable to those obtained in indoor environments $[12,15,17,29]$.

The size distribution of bioaerosols depends upon the species of microorganism, the age of the spore and the nutrient medium, differences in spore aggregation rates, as well as the type of particles they are associated with, such as mist or particulate matter [23]. Differences in size distribution may be also affected by meteorological factors, which explains the strong interaction between the two opposing mechanisms stimulating the growth and reduction of bacterial aerosols.

In order to check the assumed influence of meteorological parameters on bacterial size distribution, we checked the size distributions of bacterial aerosols at the minimum and maximum values of the 
selected meteorological parameters: ambient temperature, UV radiation, relative humidity, and wind velocity. A particularly different size distribution was observed between spring and winter for the highest and the lowest UV radiation values (Figures 5 and 6). Generally, spring conditions are better for the growth of bacterial particles, mainly for the formation of a larger cells. On the other hand, a substantial percentage of airborne bacteria died in stronger ultraviolet light. It seems that the particles most sensitive to UV radiation are single bacterial cells and, therefore, fine bacterial aerosol particles are present in lower numbers in spring and higher numbers in winter. In winter, UV radiation gradually loses importance as a bactericidal factor; on the other hand, the growth of microorganisms preferring to form in agglomerates is much slower. As a result, an increasing proportion of fine particles is observed, while the proportion of coarse grains decreases. It should be noted that the size distribution of bacterial grains mainly affects the extreme fractions.

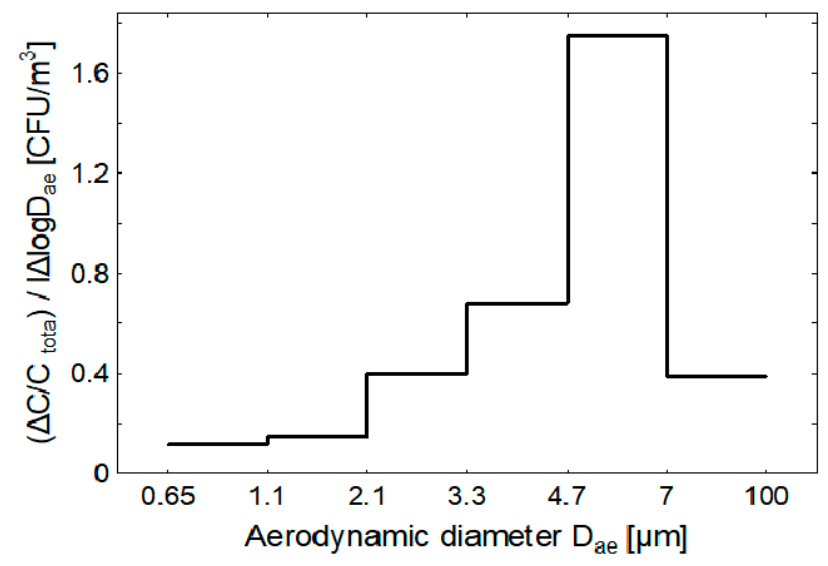

Figure 5. Size distribution of bacterial aerosols recorded at the maximum UV radiation value $\left(886 \mathrm{~W} / \mathrm{m}^{2}\right)$.

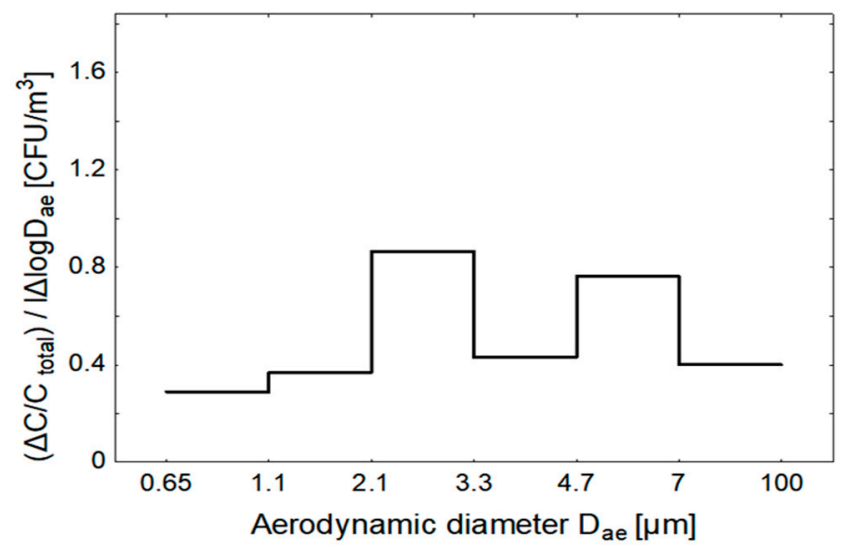

Figure 6. Size distribution of bacterial aerosols recorded at the minimum UV radiation value $\left(39 \mathrm{~W} / \mathrm{m}^{2}\right)$.

Meanwhile, bacterial particles with aerodynamic diameters measuring between 1.1 and $3.3 \mu \mathrm{m}$, do not significantly affect particle size distribution, while they can significantly alter the ratio of concentrations of respirable fractions to coarse fractions. Their levels can fluctuate strongly depending on the instantaneous values of the meteorological factors and the local bioaerosol structure. Therefore, proposals for particle size distribution are not directly transferable to the analysis of concentrations of respirable particles to coarse particles. 


\subsection{The Influence of Meteorological Factors}

The factors influencing the concentration and size distribution of culturable bacteria are very complex and include meteorological parameters, climatic conditions, source strength, and the geographical environment. Due to the great variation in weather conditions and meteorological factors, the most important factors influencing bioaerosols vary according to different seasons and locations [28]. In this study, environmental parameters such as temperature, UV radiation, relative humidity, wind velocity, as well as $\mathrm{PM}_{10}$ and $\mathrm{PM}_{2.5}$ concentrations, were measured in order to investigate whether environmental factors had any effect on bacterial aerosols. Table 1 provides a general overview of these environmental parameters during spring and winter. They were measured at the same time as the bioaerosols.

Table 1. Environmental parameters during sample collection.

\begin{tabular}{ccc}
\hline \multicolumn{3}{c}{ Outdoor Parameters, Mean \pm SD } \\
\hline Parameters & Spring & Winter \\
\hline Temperature, ${ }^{\circ} \mathrm{C}$ & $18.0 \pm 4.7$ & $-3.6 \pm 4.4$ \\
Relative humidity $(\mathrm{RH}), \%$ & $72.2 \pm 15.7$ & $77.4 \pm 11.2$ \\
Wind velocity, $\mathrm{km} / \mathrm{h}$ & $9.30 \pm 5.2$ & $14.4 \pm 6.3$ \\
$\mathrm{UV}$ radiation, $\mathrm{W} / \mathrm{m}^{2}$ & $461.1 \pm 246.5$ & $145.4 \pm 118.5$ \\
$\mathrm{PM}_{10}, \mu \mathrm{g} / \mathrm{m}^{3}$ & $27.4 \pm 21.5$ & $90.5 \pm 50.4$ \\
$\mathrm{PM}_{2.5}, \mu \mathrm{g} / \mathrm{m}^{3}$ & $12.9 \pm 8.4$ & $78.8 \pm 47.8$ \\
\hline
\end{tabular}

\subsubsection{The Influence of Temperature}

Our previous research clearly indicates that, in Poland, spring is more suitable for the survival and growth of culturable bacteria than summer [35]. Moreover, plant growth is particularly observed in spring; this may also contribute to the increase of bioaerosol sources, as well as to an increased variety of media in which microorganisms can produce and grow $[28,44]$. During the study, the temperature ranged from $8-27{ }^{\circ} \mathrm{C}$ and $-11-6.5{ }^{\circ} \mathrm{C}$ in spring and winter, respectively. The temperature ranges might suggest that bioaerosol concentrations would be significantly and positively correlated with atmospheric temperature, i.e., the concentration of bioaerosols will increase as the temperature increases.

As shown in Table 2, there is a significant positive correlation between temperature and bacterial bioaerosol concentrations in winter, but there is a negative correlation in spring. The Spearman correlation coefficient was 0.675 and $-0.316(p<0.05)$ in winter and spring, respectively.

During winter, the low temperatures decrease cell membrane fluidity and slow down microbial activity; the increased atmospheric temperature promotes the growth and release of bacteria-thus, a positive correlation is observed. On the other hand, in spring, the temperature is too high and is related to strong ultraviolet radiation. This is confirmed by a significant positive Spearman correlation coefficient of $0.687(p<0.05)$ meaning that these conditions are not suitable for the propagation and growth of plants and lead to the denaturation and inactivation of proteins [28]. 
Table 2. Spearman correlation coefficients between bacterial aerosol concentrations and environmental parameters $(n=150)$.

\begin{tabular}{|c|c|c|c|c|c|c|c|}
\hline & Bacteria & $\mathrm{T},{ }^{\circ} \mathrm{C}$ & RH, \% & $\mathrm{W}, \mathrm{km} / \mathrm{h}$ & $\mathrm{UV}, \mathrm{W} / \mathrm{m}^{2}$ & $\mathrm{PM}_{10}$ & $\mathrm{PM}_{2.5}$ \\
\hline \multicolumn{8}{|c|}{ Spring } \\
\hline Bacteria & 1 & & & & & & \\
\hline $\mathrm{T},{ }^{\circ} \mathrm{C}$ & -0.316 & 1 & & & & & \\
\hline $\mathrm{RH}, \%$ & 0.156 & -0.430 & 1 & & & & \\
\hline $\mathrm{W}, \mathrm{km} / \mathrm{h}$ & -0.040 & 0.049 & 0.063 & 1 & & & \\
\hline $\mathrm{UV}, \mathrm{W} / \mathrm{m}^{2}$ & -0.329 & 0.687 & -0.497 & 0.148 & 1 & & \\
\hline $\mathrm{PM}_{10}$ & -0.067 & 0.121 & -0.308 & -0.361 & 0.337 & 1 & \\
\hline $\mathrm{PM}_{2.5}$ & 0.020 & 0.080 & 0.037 & -0.509 & 0.090 & 0.616 & 1 \\
\hline \multicolumn{8}{|c|}{ Winter } \\
\hline Bacteria & 1 & & & & & & \\
\hline $\mathrm{T},{ }^{\circ} \mathrm{C}$ & 0.675 & 1 & & & & & \\
\hline $\mathrm{RH}, \%$ & 0.351 & 0.397 & 1 & & & & \\
\hline $\mathrm{W}, \mathrm{km} / \mathrm{h}$ & -0.102 & -0.201 & -0.043 & 1 & & & \\
\hline $\mathrm{UV}, \mathrm{W} / \mathrm{m}^{2}$ & -0.603 & -0.640 & -0.614 & 0.070 & 1 & & \\
\hline $\mathrm{PM}_{10}$ & -0.301 & -0.209 & -0.218 & -0.053 & 0.176 & 1 & \\
\hline $\mathrm{PM}_{2.5}$ & -0.261 & -0.138 & -0.161 & -0.119 & 0.123 & 0.984 & 1 \\
\hline
\end{tabular}

Italic entries indicate that the correlation is significant at the 0.05 level; Temperature, $\mathrm{T}\left({ }^{\circ} \mathrm{C}\right)$; Relative humidity, $\mathrm{RH}(\%)$; Wind velocity, $\mathrm{W}(\mathrm{km} / \mathrm{h})$; UV radiation, $\mathrm{UV}\left(\mathrm{W} / \mathrm{m}^{2}\right)$; concentration of particulate matter $\mathrm{PM}_{10}$ and $\mathrm{PM}_{2.5}\left(\mu \mathrm{g} / \mathrm{m}^{3}\right)$.

\subsubsection{The Influence of UV Radiation}

Solar radiation is known to constitute an effective sterilization method for bioaerosols [29]. During our study, UV radiation was significantly different for each season. The average UV radiation was $461.1 \mathrm{~W} / \mathrm{m}^{2}$ and $145.4 \mathrm{~W} / \mathrm{m}^{2}$ in spring and winter, respectively. Table 2 shows the correlation between bacterial aerosol concentrations and UV radiation. During both seasons, we observed a statistically significant negative relationship between bacterial aerosol concentrations and UV radiation. The Spearman correlation coefficient was -0.329 and $-0.603(p<0.05)$ in spring and winter, respectively. Therefore, airborne bacteria in Gliwice would be more likely to propagate and grow at relatively low UV radiation levels, whereas a comparatively high UV radiation value would inhibit their growth.

\subsubsection{The Influence of Relative Humidity (RH)}

The viability of bioaerosols becomes inhibited if RH is too low, because a dry environment will decrease the metabolism and physiological activities of microorganisms. The RH in Gliwice ranged from $44-97 \%$ and $56-94 \%$ in spring and winter, respectively. The average RH was relatively stable and changed little between seasons; the average was $72.2 \%$ and $77.4 \%$ in spring and winter, respectively (Table 1). Positive correlations were found between concentrations of viable bacteria and RH. This was consistent with the results reported by Li et al. [45]. As indicated in Table 2, the correlation was higher and only statistically significant in winter $(p<0.05)$. According to Jones and Harrison [46], moisture in the air could alter the integrity of cell walls and viral coats and, thus, increased air humidity could promote the growth and release of bacteria.

\subsubsection{The Influence of Wind Velocity}

Generally, wind has been confirmed to have an effect on bioaerosols, varying according to different speeds and directions. For example Montero et al. [47] reported that during summer season wind speed and total coarse bioaerosols were significantly correlated. Wind velocity is clearly associated with the release and dispersal of spores, although its effect varies according to its intensity and the height at which it is recorded. Wind speeds that exceed a threshold value will accelerate the process of 
releasing microbes from soil or plant surfaces by blowing them off or moving them. However, at high wind speeds, microbial concentrations will become diluted [46]. In our study, the Spearman correlation coefficient was -0.040 and $-0.102(p>0.05)$ in spring and winter, respectively. Therefore, there was no relationship between wind velocity and bacterial aerosol concentrations in either season. This result is in a good agreement with the observations of $\mathrm{Li}$ et al. [26,48]. To find, however, a more precise relationship between the level of airborne bacteria and wind speed very large datasets should be analyzed. Especially, it is important to measure the concentration of bacterial aerosols for the velocity of wind ranging from less than $1 \mathrm{~km} \mathrm{~h}^{-1}$ to more than $20 \mathrm{~km} \mathrm{~h}^{-1}$.

\subsubsection{The Influence of PM}

Bioaerosols, including moulds and yeasts, bacteria, and viruses, as well as particles of plant origin pollens and algae, are bound to PM and, therefore, its biological and morphological characteristics may undergo considerable changes. In Poland, this phenomenon might be particularly important in winter due to high PM emissions from coal-based domestic sources [49]. Changes in microbial dispersal patterns and aerodynamic diameters could lead to variations in deposition locations in human respiratory tracts. At high PM concentrations, the potential synergistic effects between biological and chemical pollutants may further intensify their hazardous effects on human health [34]. Polish legislation [50] specifies a $24 \mathrm{~h}$ mean concentration of $\mathrm{PM}_{10}$ in ambient air, which is $50 \mu \mathrm{g} / \mathrm{m}^{3}$. $\mathrm{PM}_{2.5}$ has no corresponding short term $(24 \mathrm{~h})$ limit, but there is an annual limit of $25 \mu \mathrm{g} / \mathrm{m}^{3}$. The World Health Organization (WHO) is more strict in this regard: for $\mathrm{PM}_{2.5}$, it recommends a $24 \mathrm{~h}$ average standard of $25 \mu \mathrm{g} / \mathrm{m}^{3}$ [51] and recommends applying the same guidelines to ambient air as for indoor spaces [52]. During the spring part of the study, the average concentrations of $\mathrm{PM}_{10}$ and $\mathrm{PM}_{2.5}$ (27.4 and $12.9 \mu \mathrm{g} / \mathrm{m}^{3}$ ) did not exceed Polish and WHO guidelines. However, in winter, the $\mathrm{PM}_{10}$ standard was exceeded by roughly $60 \%$ and the $\mathrm{PM}_{2.5}$ standard was exceeded by more than $300 \%$. In spring, no consistent relationship between PM and bioaerosols was observed; however, in winter, a decrease in culturable airborne bacteria was observed as $\mathrm{PM}_{10}$ and $\mathrm{PM}_{2.5}$ concentrations increased. The Spearman correlation coefficient was 0.301 and $-0.261(p>0.05)$ for $\mathrm{PM}_{10}$ and $\mathrm{PM}_{2.5}$, respectively. Therefore, a weak negative relationship was found between PM and bacterial aerosol in winter. A possible reason for this is that winter PM contains components that have a negative effect on the cultivation and survival of bioaerosols [34].

\section{Conclusions}

The term "bioaerosol" is not very clearly defined and is frequently used with different meanings, we focused only on bacterial aerosol. This study provided information on the concentrations and size distribution of ambient culturable bacteria in Gliwice City during spring and winter. The average concentration of culturable bacterial aerosols in outdoor air differed significantly over the study period. The average values were $355 \pm 222 \mathrm{CFU} \mathrm{m}{ }^{-3}$ and $65 \pm 53 \mathrm{CFU} \mathrm{m}^{-3}$ in spring and winter, respectively. The highest concentrations of bacterial aerosol were recorded during spring $\left(1124 \mathrm{CFU} \mathrm{m}{ }^{-3}\right)$, while the

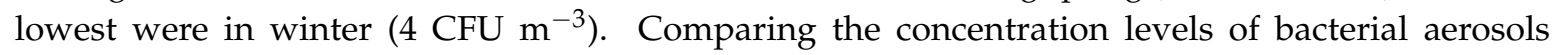
with those recorded in other studies, it can be concluded that the atmospheric air in Gliwice is relatively clean, microbiologically. The examination of seasonal size distributions of bacterial grains clearly indicated that during the cooler season, the size distribution is more "flattened" and is also characterized by an increased contribution of fine bioparticles and a decreased contribution of coarse bacteria. Another important finding was that more than $50 \%$ of bacterial aerosols fell within the respiratory range.

We analysed the correlation between bacterial aerosol concentrations and meteorological parameters. Statistically, the most important meteorological factors in the viability of airborne bacteria were temperature (T) and UV radiation (UV). In spring, the Spearman correlation coefficients for T or UV with bacterial aerosol concentrations were -0.316 and $-0.329(p<0.05)$ and 0.675 and -0.603 $(p<0.05)$ in spring and winter, respectively. The influence of UV radiation was negative during both 
seasons. Low UV radiation led to higher airborne bacteria concentrations, while high RH contributed to lower bacterial aerosol concentrations. However, the temperature had a different impact in spring and in winter. During winter, a strong positive correlation was observed between temperature and bacterial aerosol concentrations. These concentrations were high in relatively warm temperatures and were low in cooler temperatures. During spring, the opposite was observed. The higher temperature decreased the ability of ambient bacteria to survive. This dependence was caused by the significant correlation between temperature and UV radiation. The Spearman correlation coefficients between T and UV were of 0.687 and $-0.640(p<0.05)$ in spring and winter, respectively. Relative humidity was positively correlated with bacterial aerosol concentrations; however, this relationship was only statistically significant in winter $(0.351 ; p<0.05)$. Wind velocity was found to have no statistically significant correlation with bacterial aerosol concentrations. The statistically significant weak relationship between bacterial aerosols and particulate matter was only observed in winter. The Spearman correlation coefficients were -0.301 and -0.261 for $\mathrm{PM}_{10}$ and $\mathrm{PM}_{2.5}$, respectively; therefore, high $\mathrm{PM}_{10}$ and $\mathrm{PM}_{2.5}$ levels during winter could reduce bacterial viability.

In addition to the limitations of the culture-based method employed in the present study (a culture-based method employed in the present study probably accounts for only $\sim 10 \%$ of the total microorganisms), the results of this campaign may still be useful in developing control devices for bacterial aerosols and in predicting of the occurrence of diseases caused by bioaerosols. However, to precisely anticipate the adverse health effects caused by the exposure to airborne bacteria the taxonomic identification of collected bacterial particles should be made. If not, the typical percentage of genera/species in the total bacteria concentration around the sampling point could be assumed using the literature data. It should be noted that such approach may be applied in the preliminary assessment of the influence of bacterial aerosol on the human health only.

Acknowledgments: This work was supported by the Faculty of Power and Environmental Engineering, Silesian University of Technology (statutory research).

Author Contributions: Ewa Bragoszewska performed the measurements and drafted the manuscript. Anna Mainka prepared the final manuscript. Jozef S. Pastuszka helped with the data analysis.

Conflicts of Interest: The authors declare no conflict of interest.

\section{References}

1. Bowers, R.M.; McCubbin, I.B.; Hallar, A.G.; Fierer, N. Seasonal variability in airborne bacterial communities at a high-elevation site. Atmos. Environ. 2012, 50, 41-49. [CrossRef]

2. Lighthart, B. Mini-review of the concentration variations found in the alfresco atmospheric bacterial populations. Aerobiologia (Bologna) 2000, 16, 7-16. [CrossRef]

3. Nevalainen, A.; Willeke, K.; Liebhaber, F.; Pastuszka, J.S.; Burge, H.; Henningson, E. Bioaerosol sampling. In Aerosol Measurement: Principles, Techniques and Applications; Willeke, K., Baron, P., Eds.; Van Nostrand Reinhold: New York, NY, USA, 1993; pp. 471-492.

4. Ege, M.; Mayer, M.; Normand, A.; Genuneit, J.; Cookson, W.; Braun-Fahrlander, C.; Heederik, D.; Piarroux, R.; Von Mutius, E. Exposure to environmental microorganisms and its inverse relation to childhood asthma. Allergy Eur. J. Allergy Clin. Immunol. 2011, 66, 57.

5. Kallawicha, K.; Lung, S.C.C.; Chuang, Y.C.; Wu, C.D.; Chen, T.H.; Tsai, Y.J.; Chao, H.J. Spatiotemporal distributions and land-use regression models of ambient bacteria and endotoxins in the greater Taipei area. Aerosol Air Qual. Res. 2015, 15, 1448-1459. [CrossRef]

6. Uk Lee, B.; Lee, G.; Joon Heo, K. Concentration of culturable bioaerosols during winter. J. Aerosol Sci. 2016, 94, 1-8. [CrossRef]

7. Wu, Y.H.; Chan, C.C.; Chew, G.L.; Shih, P.W.; Lee, C.T.; Chao, H.J. Meteorological factors and ambient bacterial levels in a subtropical urban environment. Int. J. Biometeorol. 2012, 56, 1001-1009. [CrossRef] [PubMed]

8. Douwes, J.; Thorne, P.; Pearce, N.; Heederik, D. Bioaerosol Health Effects and Exposure Assessment: Progress and Prospects. Ann. Occup. Hyg. 2003, 47, 187-200. [CrossRef] [PubMed] 
9. Ross, M.A.; Curtis, L.; Scheff, P.A.; Hryhorczuk, D.O.; Ramakrishnan, V.; Wadden, R.A.; Persky, V.W. Association of asthma symptoms and severity with indoor bioaerosols. Allergy 2000, 55, 705-711. [CrossRef] [PubMed]

10. Després, V.R.; Alex Huffman, J.; Burrows, S.M.; Hoose, C.; Safatov, A.S.; Buryak, G.; Fröhlich-Nowoisky, J.; Elbert, W.; Andreae, M.O.; Pöschl, U.; et al. Primary biological aerosol particles in the atmosphere: A review. Tellus Ser. B Chem. Phys. Meteorol. 2012, 64. [CrossRef]

11. Brass, D.M.; Hollingsworth, J.W.; Cinque, M.; Li, Z.; Potts, E.; Toloza, E.; Foster, W.M.; Schwartz, D.A. Chronic LPS inhalation causes emphysema-like changes in mouse lung that are associated with apoptosis. Am. J. Respir. Cell Mol. Biol. 2008, 39, 584-590. [CrossRef] [PubMed]

12. Nasir, Z.A.; Colbeck, I. Assessment of bacterial and fungal aerosol in different residential settings. Water Air. Soil Pollut. 2010, 211, 367-377. [CrossRef]

13. Nasir, Z.A.; Mula, V.; Stokoe, J.; Colbeck, I.; Loeffler, M. Evaluation of total concentration and size distribution of bacterial and fungal aerosol in healthcare built environments. Indoor Built Environ. 2015, 24, 269-279. [CrossRef]

14. Pegas, P.N.; Evtyugina, M.G.; Alves, C.A.; Nunes, T.; Cerqueira, M.; Franchi, M.; Pio, C.; Almeida, S.M.; Freitas, M.C. Outdoor/Indoor Air Quality in Primary Schools in Lisbon: A Preliminary Study. Quim. Nova 2010, 33, 1145-1149. [CrossRef]

15. Pastuszka, J.S.; Kyaw Tha Paw, U.; Lis, D.O.; Wlazło, A.; Ulfig, K. Bacterial and fungal aerosol in indoor environment in Upper Silesia, Poland. Atmos. Environ. 2000, 34, 3833-3842. [CrossRef]

16. Bartlett, K.H.; Kennedy, S.M.; Brauer, M.; van Netten, C.; Dill, B. Evaluation and determinants of airborne bacterial concentrations in school classrooms. J. Occup. Environ. Hyg. 2004, 1, 639-647. [CrossRef] [PubMed]

17. Bragoszewska, E.; Mainka, A.; Pastuszka, J. Bacterial and Fungal Aerosols in Rural Nursery Schools in Southern Poland. Atmosphere (Basel) 2016, 7, 142. [CrossRef]

18. Menteşe, S.; Arisoy, M.; Rad, A.Y.; Güllü, G. Bacteria and fungi levels in various indoor and outdoor environments in Ankara, Turkey. Clean-Soil Air Water 2009, 37, 487-493. [CrossRef]

19. Mentese, S.; Rad, A.Y.; Arisoy, M.; Gullu, G. Seasonal and Spatial Variations of Bioaerosols in Indoor Urban Environments, Ankara, Turkey. Indoor Built Environ. 2012, 21, 797-810. [CrossRef]

20. Ghosh, B.; Lal, H.; Srivastava, A. Review of bioaerosols in indoor environment with special reference to sampling, analysis and control mechanisms. Environ. Int. 2015, 85, 254-272. [CrossRef] [PubMed]

21. Górny, R.L.; Dutkiewicz, J. Bacterial and Fungal Aerosols in Indoor Environment in Central and Eastern European Countries. Ann Agric Environ. Med. 2002, 9, 17-23. [PubMed]

22. Gołofit-Szymczak, M.; Górny, R.L. Bacterial and fungal aerosols in air-conditioned office buildings in Warsaw, Poland-The winter season. Int. J. Occup. Saf. Ergon. 2010, 16, 465-476. [CrossRef] [PubMed]

23. Bragoszewska, E.; Mainka, A.; Pastuszka, J.S. Bacterial aerosols in an urban nursery school in Gliwice, Poland: A case study. Aerobiologia (Bologna) 2016, 32, 469-480. [CrossRef]

24. Mouli, P.C.; Mohan, S.V.; Reddy, S.J. Assessment of microbial (bacteria) concentrations of ambient air at semi-arid urban region: Influence of meteorological factors. Appl. Ecol. Environ. Res. 2005, 3, 139-149. [CrossRef]

25. Hurtado, L.; Rodríguez, G.; López, J.; Castillo, J.E.; Molina, L.; Zavala, M.; Quintana, P.J.E. Characterization of atmospheric bioaerosols at 9 sites in Tijuana, Mexico. Atmos. Environ. 2014, 96, 430-436. [CrossRef]

26. Li, M.; Qi, J.; Zhang, H.; Huang, S.; Li, L.; Gao, D. Concentration and size distribution of bioaerosols in an outdoor environment in the Qingdao coastal region. Sci. Total Environ. 2011, 409, 3812-3819. [CrossRef] [PubMed]

27. Dong, L.; Qi, J.; Shao, C.; Zhong, X.; Gao, D.; Cao, W.; Gao, J.; Bai, R.; Long, G.; Chu, C. Concentration and size distribution of total airborne microbes in hazy and foggy weather. Sci. Total Environ. 2016, 541, 1011-1018. [CrossRef] [PubMed]

28. Zhong, X.; Qi, J.; Li, H.; Dong, L.; Gao, D. Seasonal distribution of microbial activity in bioaerosols in the outdoor environment of the Qingdao coastal region. Atmos. Environ. 2016, 140, 506-513. [CrossRef]

29. Li, Y.; Lu, R.; Li, W.; Xie, Z.; Song, Y. Concentrations and size distributions of viable bioaerosols under various weather conditions in a typical semi-arid city of Northwest China. J. Aerosol Sci. 2017, 106, 83-92. [CrossRef]

30. Yamamoto, N.; Bibby, K.; Qian, J.; Hospodsky, D.; Rismani-Yazdi, H.; Nazaroff, W.W.; Peccia, J. Particle-size distributions and seasonal diversity of allergenic and pathogenic fungi in outdoor air. ISME J. 2012, 6, 1801-1811. [CrossRef] [PubMed] 
31. Dueker, M.E.; O'Mullan, G.D.; Juhl, A.R.; Weathers, K.C.; Uriarte, M. Local environmental pollution strongly influences culturable bacterial aerosols at an urban aquatic superfund site. Environ. Sci. Technol. 2012, 46, 10926-10933. [CrossRef] [PubMed]

32. Dueker, M.E.; Weathers, K.C.; O'Mullan, G.D.; Juhl, A.R.; Uriarte, M. Environmental controls on coastal coarse aerosols: Implications for microbial content and deposition in the near-shore environment. Environ. Sci. Technol. 2011, 45, 3386-3392. [CrossRef] [PubMed]

33. Dueker, M.E.; O'Mullan, G.D. Aeration remediation of a polluted waterway increases near-surface coarse and culturable microbial aerosols. Sci. Total Environ. 2014, 478, 184-189. [CrossRef] [PubMed]

34. Gao, M.; Yan, X.; Qiu, T.; Han, M.; Wang, X. Variation of correlations between factors and culturable airborne bacteria and fungi. Atmos. Environ. 2016, 128, 10-19. [CrossRef]

35. Bragoszewska, E. Bacterial Aerosol Occurring in the Atmospheric Air in Gliwice and Its Share of the Total Human Exposure to the Bacteria Absorbed by Inhalation. Ph.D. Thesis, Silesian University of Technology, Gliwice, Poland, 2014.

36. Nevalainen, A.; Pastuszka, J.; Liebhaber, F.; Willeke, K. Performance of bioaerosol samplers: Collection characteristics and sampler design considerations. Atmos. Environ. Part A Gen. Top. 1992, 26, 531-540. [CrossRef]

37. PN-EN 12322: 2005. In Vitro Diagnostic Medical Devices. Culture Media for Microbiology. Performance Criteria for Culture Media; Polish Committee for Standardization (PKN): Warsaw, Poland, 2005.

38. ISO 11133:2014. Microbiology of Food, Animal Feed and Water-Preparation, Production, Storage and Performance Testing of Culture Media; BSI (British Standards Institution): London, UK, 2014.

39. Heo, K.J.; Kim, H.B.; Lee, B.U. Concentration of environmental fungal and bacterial bioaerosols during the monsoon season. J. Aerosol Sci. 2014, 77. [CrossRef]

40. Lighthart, B.; Stetzenbach, L.D. Distribution of Microbial Bioaerosol. In Atmospheric Microbial Aerosols: Theory and Applications; Lighthart, B., Mohr, A.J., Eds.; Springer: Boston, MA, USA, 1994; pp. 68-98, ISBN 978-1-4684-6438-2.

41. Genitsaris, S.; Stefanidou, N.; Katsiapi, M.; Kormas, K.A.; Sommer, U.; Moustaka-Gouni, M. Variability of airborne bacteria in an urban Mediterranean area (Thessaloniki, Greece). Atmos. Environ. 2017, 157, 101-110. [CrossRef]

42. Górny, R.L. Biological aerosols-A role of hygienic standards in the protection of environment and health. Med. Środowiskowa 2010, 13, 2009-2010.

43. Goyer, N.; Lavoie, J.; Lazure, L.; Marchand, G. Bioaerosols in the Workplace: Evaluations, Control and Prevention Guide; IRSST, Occupational Health and Safety Research Institute Robert Sauvé: Montreal, QC, Canada, 2001.

44. Kurkela, T. The number of Cladosporium conidia in the air in different weather conditions The number of Cladosporium conidia in the air in different weather conditions. Grana 1997, 36, 54-61. [CrossRef]

45. Li, Y.; Fu, H.; Wang, W.; Liu, J.; Meng, Q.; Wang, W. Characteristics of bacterial and fungal aerosols during the autumn haze days in Xi'an, China. Atmos. Environ. 2015, 122, 439-447. [CrossRef]

46. Jones, A.M.; Harrison, R.M. The effects of meteorological factors on atmospheric bioaerosol concentrations-A review. Sci. Total Environ. 2004, 326, 151-180. [CrossRef] [PubMed]

47. Montero, A.; Dueker, M.E.; O'Mullan, G.D. Culturable bioaerosols along an urban waterfront are primarily associated with coarse particles. Peer] 2016, 4, e2827. [CrossRef] [PubMed]

48. Li, M.; Yu, X.; Kang, H.; Xie, Z.; Zhang, P. Concentrations and size distributions of bacteria-containing particles over oceans from China to the Arctic ocean. Atmosphere (Basel) 2017, 8, 82. [CrossRef]

49. Zajusz-Zubek, E.; Mainka, A.; Korban, Z.; Pastuszka, J.S. Evaluation of highly mobile fraction of trace elements in PM10 collected in Upper Silesia (Poland): Preliminary results. Atmos. Pollut. Res. 2015, 6, 1-2. [CrossRef]

50. Dz, U. Polish Journal of Laws (Journal of Laws) Regulation of the Minister of Environment of 13 September 2012, No. 1031-The Levels of Certain Substances in the Ambient Air; Minister of Polish Law: Warsaw, Poland, 2012.

51. WHO. Air Quality Guidelines for Particulate Matter, Ozone, Nitrogen Dioxide and Sulfur Dioxide; WHO: Geneva, Switzerland, 2006.

52. Mainka, A.; Bragoszewska, E.; Kozielska, B.; Pastuszka, J.S.; Zajusz-Zubek, E. Indoor air quality in urban nursery schools in Gliwice, Poland: Analysis of the case study. Atmos. Pollut. Res. 2015, 6, 1098-1104. [CrossRef]

(C) 2017 by the authors. Licensee MDPI, Basel, Switzerland. This article is an open access article distributed under the terms and conditions of the Creative Commons Attribution (CC BY) license (http://creativecommons.org/licenses/by/4.0/). 